\title{
RANCANG BANGUN SISTEM JUAL BELI HEWAN TERNAK BERBASIS WEB
}

\author{
Putri Alya Zahra ${ }^{1}$, Ahsani Takwim², Siti Nuraini ${ }^{3}$, Dicky Abdinur Dwiputra ${ }^{4}$, Ichsan Fadilah ${ }^{5}$ \\ Program Studi Managemen Keuangan Syariah ${ }^{1,3}$, Program Studi Teknik Informatika ${ }^{2,4,5}$ \\ UIN Sunan Gunung Djati Bandung ${ }^{1,3}$, Sekolah Tinggi Teknologi Bandung ${ }^{2,4,5}$ \\ putrialyazhr@gmail.com¹, ahsanitakwim@sttbandung.ac.id², abc.nura13@gmail.com³, dickyabdinur06@gmail.com \\ ichsanfadil2341@gmail.com ${ }^{5}$
}

\begin{abstract}
Abstrak
Kebutuhan akan hewan ternak semakin hari samakin meningkat baik untuk dikonsumsi, dikembangbiakan kembali, maupun dijual kembali. Oleh karena itu, pemilihan kualitas hewan sangat penting untuk pembeli, kondisi hewan harus dalam keadaan sehat dan sesuai syarat yang sudah ditentukan. Selain itu, proses transaksi juga harus mudah.

Perkembangan teknologi yang semakin hari semakin pesat bias dijadikan solusi atas permasalah yang ada. Pada penelitian kali ini penulis membuat aplikasi jual beli hewan ternak berbasis web. Ini dimaksudkan agar pembeli terhubung dengan sistem yang terintegrasi. Sehingga, memudahkan bisa memudahkan pembeli saat melakukan pembelian. Tujuan dari penelitian ini adalah untuk merancang aplikasi yang dapat membantu dalam melakukan proses transsaksi pembelian hewan ternak dengan mudah.

Kata kunci: Sistem, Aplikasi, Penjualan

Abstract

The need for livestock is increasing day by day both for consumption, re-breeding, and resale. Therefore, the selection of the quality of the animal is very important for the buyer, the condition of the animal must be in good health and according to the conditions that have been determined. In addition, the transaction process must also be easy and appropriate.

The development of technology that is increasingly rapidly can be used as a solution to existing problems. In this research, the author makes a web-based application for buying and selling livestock. This is intended so that buyers are connected to an integrated system. This makes it easier for buyers to make purchases. The purpose of this research is to design an application that can assist in the transaction process of purchasing livestock easily

Keywords: System, Application, Sales
\end{abstract}

\section{PENDAHULUAN}

Website adalah media yang digunakan untuk menampung data teks, gambar, suara, dan animasi yang dapat ditampilkan di internet dan dapat diakses oleh komputer yang terhubung dengan internet secara global. Website merupakan media informasi berbasis jaringan komputer yang dapat diakses di mana saja dengan biaya relatif murah. Website merupakan bentuk implementasi dari bahasa pemograman web (web programming). PHP (Hypertext Preprocessor) merupakan bahasa pemrograman berbasis web yang memiliki kemampuan untuk memproses dan mengolah data secara dinamis.

Hewan ternak merupakan hewan yang dipelihara dari segala aspek untuk dibiakkan dengan tujuan produksi untuk menghasilkan telur, susu, daging, dan lainnya. Ada banyak hewan yang bisa diternak tergantung dengan daerah asal, budaya, dan topografi. Peternakan sering dilakukan pada kelompok hewan unggas, seperti ayam, bebek, itik dan mamalia, seperti, sapi, kambing, dan domba. Selain itu, berbagai jenis serangga hingga reptil juga bisa diternak, namun untuk diperjual belikan bukan dikonsumsi.

\section{TINJAUAN PUSTAKA}

\section{Sistem}

Pendapat ahli menyatakan bahwa "sistem bisa diartikan sebagai sekumpulan sub sistem, komponen yang saling bekerja sama dengan tujuan yang sama untuk menghasilkan output yang sudah ditentukan sebelumnya"[1]. Sistem adalah kumpulan orang yang saling bekerja sama dengan ketentuan-ketentuan aturan yang sistematis dan terstruktur untuk membentuk satu kesatuan yang melaksanakan suatu fungsi untuk mencapai tujuan. Sistem memiliki beberapa karakteristik atau sifat yang terdiri dari komponen sistem, batasan sistem, lingkungan luar sistem, penghubung sistem, masukan sistem, keluaran sistem, pengolahan sistem dan sasaran sistem. Sedangkan informasi adalah data yang diolah menjadi lebih berguna dan berarti bagi penerimanya, serta untuk mengurangi ketidakpastian dalam proses pengambilan keputusan mengenai suatu keadaan. Sistem Informasi merupakan suatu kombinasi teratur dari orangorang, hardware, software, jaringan komunikasi dan sumber daya data yang mengumpulkan, mengubah, dan menyebarkan informasi dalam sebuah organisasi[2].

\section{Website}

Bekti mengemukakan bahwa website merupakan kumpulan halaman-halaman yang digunakan untuk menampilkan informasi teks, gambar diam atau gerak, animasi, suara,dan atau gabungan dari semuanya, baik yang bersifat statis maupun dinamis yang membentuk satu rangkaian bangunan yang saling terkait, yang masingmasing dihubungkan dengan jaringan-jaringan halaman[3]. 


\section{UML (Unified Modelling Language)}

Menurut Rosa Dan Shalahuddin dalam bukunya mengatakan "UML (Unified Modelling Language) adalah salah satu standar bahasa yang banyak digunakan didunia industri untuk mendefinisikan requirement, membuat analisis dan desain, serta menggambarkan arsitektur dalam pemrograman berorientasikan objek[4]. Dapat didefinisikan $U M L$ adalah standar bahasa untuk mendefinisikan dari requirement, membuat analisa \& desain dan menggambarkan arsitektur dalam pemrograman yang berorientasi pada objek.

\section{Peternakan}

Peternakan adalah kegiatan mengembangbiakkan dan membudidayakan hewan ternak untuk mendapatkan manfaat dan hasil dari kegiatan tersebut. Pengertian peternakan tidak terbatas pada pemeliharaaan saja, memelihara dan peternakan perbedaannya terletak pada tujuan yang ditetapkan. Tujuan peternakan adalah mencari keuntungan dengan penerapan prinsip-prinsip manajemen pada faktor-faktor produksi yang telah dikombinasikan secara optimal [5].

\section{Ternak}

Menurut ahli, ternak adalah hewan piara, yang kehidupannya yakni mengenai tempat, perkembanganbiakannya serta manfaatnya diatur dan diawasi oleh manusia serta dipelihara khusus sebagai penghasil bahan-bahan dan jasajasa yang berguna bagi kepentingan hidup manusia[6]. Pendapat lain mengatakan bahwa ternak adalah hewan peliharaan yang produknya diperuntukkan sebagai penghasil pangan, bahan baku industri, jasa, dan/atau hasil ikutannya yang terkait dengan pertanian[7].

\section{ANALISIS DAN PERANCANGAN}

\section{Metode Penelitian}

Penulis dalam membuat penelitian ini menggunakan metodologi penelitian kuantitatif dengan metode pengembangan perangkat lunak Extreme Programming $(X P)$. Tahapan dalam XP yang penulis gunakan dalam bab ini yaitu, Perancangan dan Desain.

2. Desain

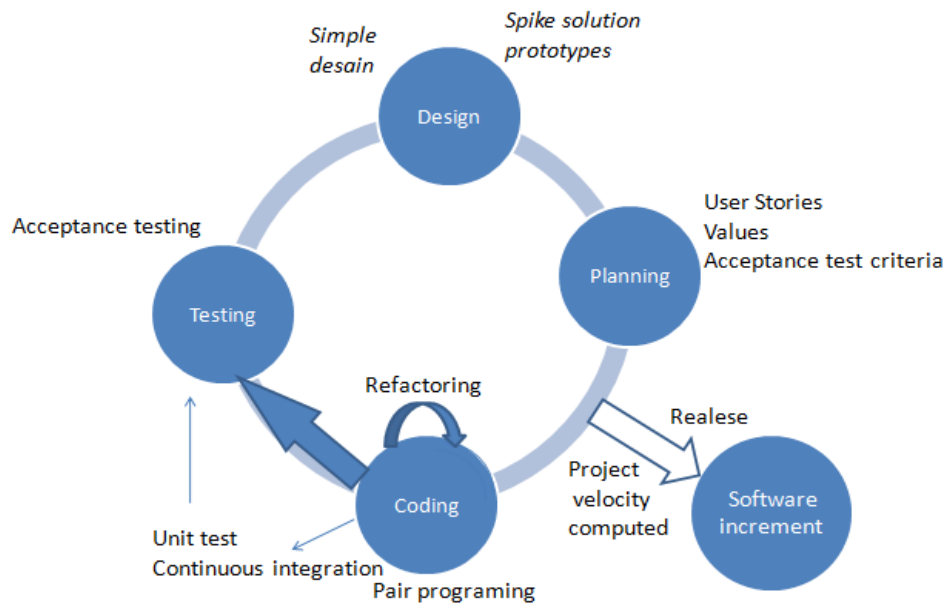

Gambar 1. Extreme Programming

a. Login

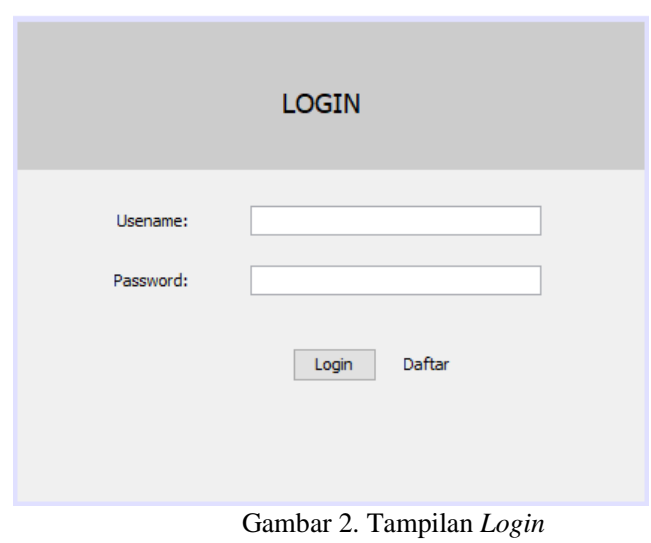


Gambar 2 merupakan tampilan saat user melakukan login pada aplikasi, jika user sudah memiliki akun user tinggal melakukan login dengan memasukan username dan password.

b. Daftar

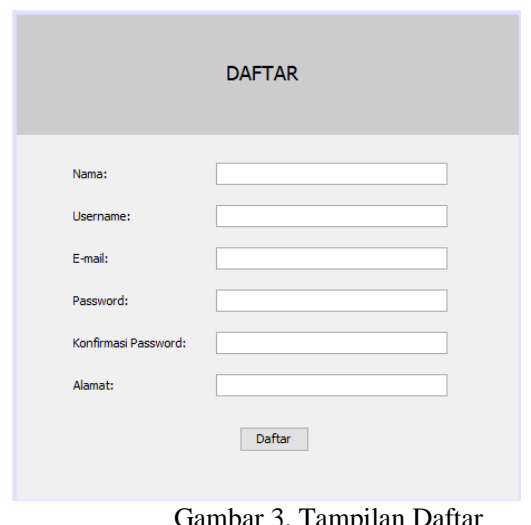

Gambar 3 merupakan tampilan ketika user melakukan pendaftaran pada aplikasi jika user belum memiliki akun. Pada menu ini user akan memasukan nama, username, email, password, dan alamat.

c. Menu Utama

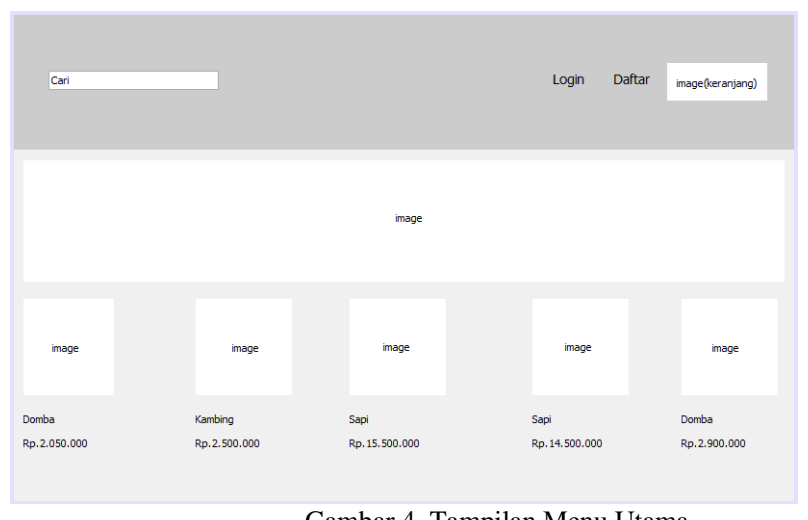

Gambar 4. Tampilan Menu Utama

Gambar 4 merupakan tampilan menu utama aplikasi setelah user melakukan berhasil melakukan login. Pada menu ini terdapat pilihan hewan yang bisa dibeli oleh user, user juga bisa mencari secara spesifik hewan yang ingin dicari melalui bagian pencarian.

\section{d. Detail Hewan}

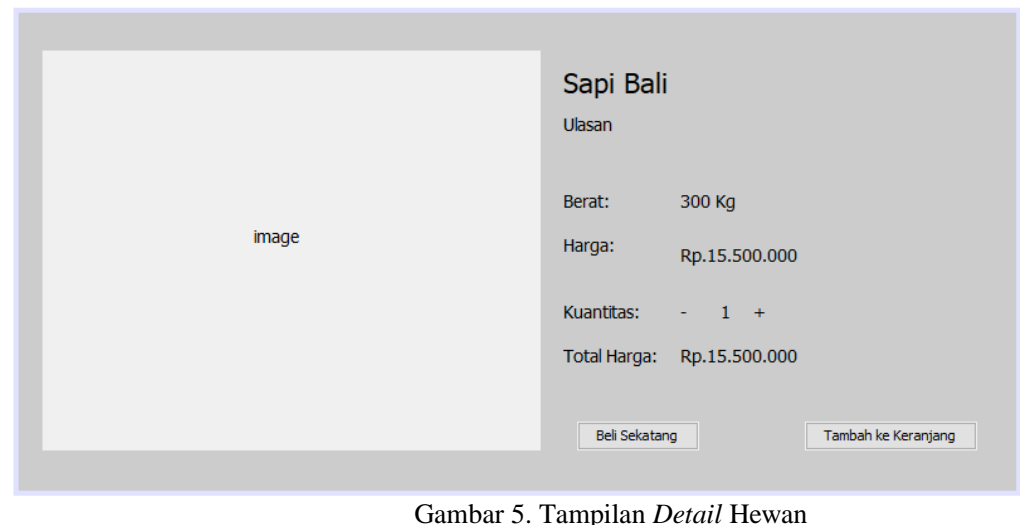

Gambar 5 merupakan tampilan menu detail hewan yang akan dibeli oleh user, pada menu ini user bisa memilih jumlah hewan yang akan dibeli dan bisa memasukannya ke keranjang terlebih dahulu. 
e. Checkout

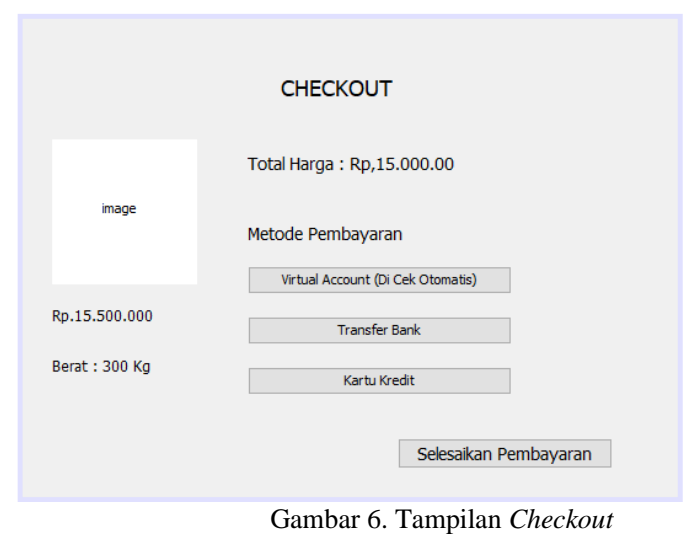

Gambar 6 merupakan tampilan pada menu checkout, pada tampilan ini user akan memilih metode pembayaran dan melakukan pembayaran

f. Pembayaran Sukses

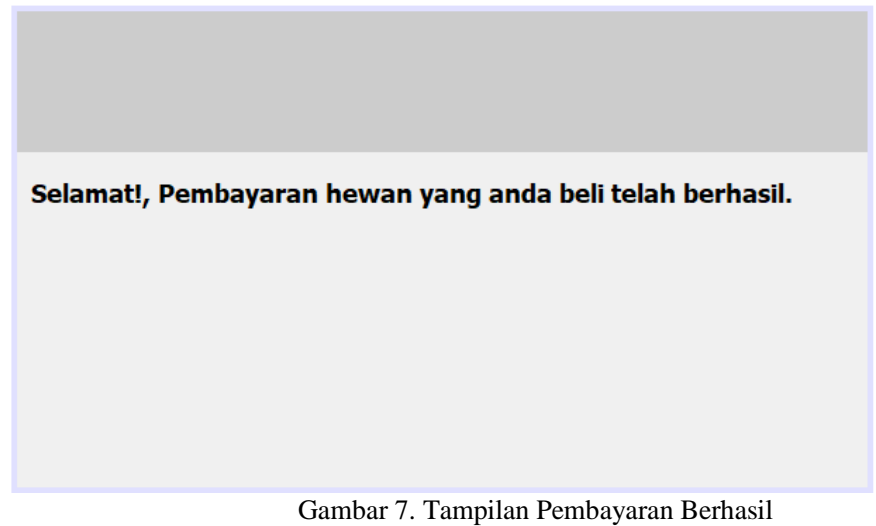

Gambar 7 merupakan tampilan ketika user berhasil melakukan pembayaran.

3. Gambaran Umum Sistem

a. Use Case Diagram

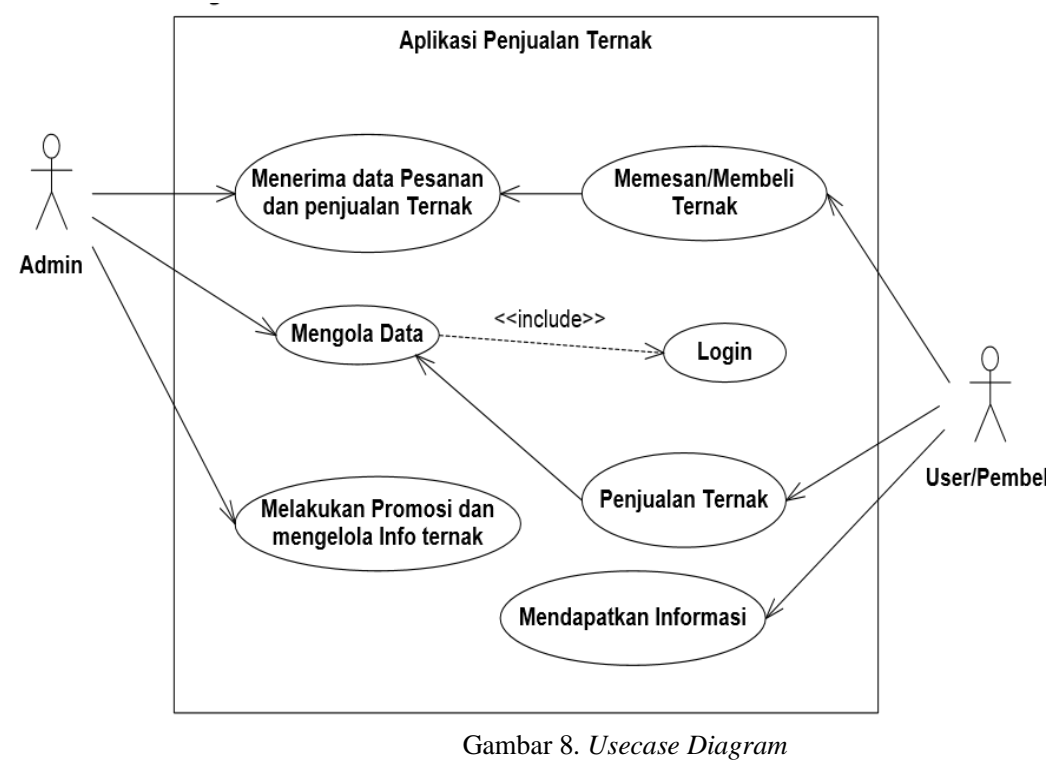

Pada penelitian ini use case melibatkan 2 aktor yaitu admin dan user. 
b. Class Diagram

Rancangan class diagram pada penelitian ini adalah sebagai berikut:

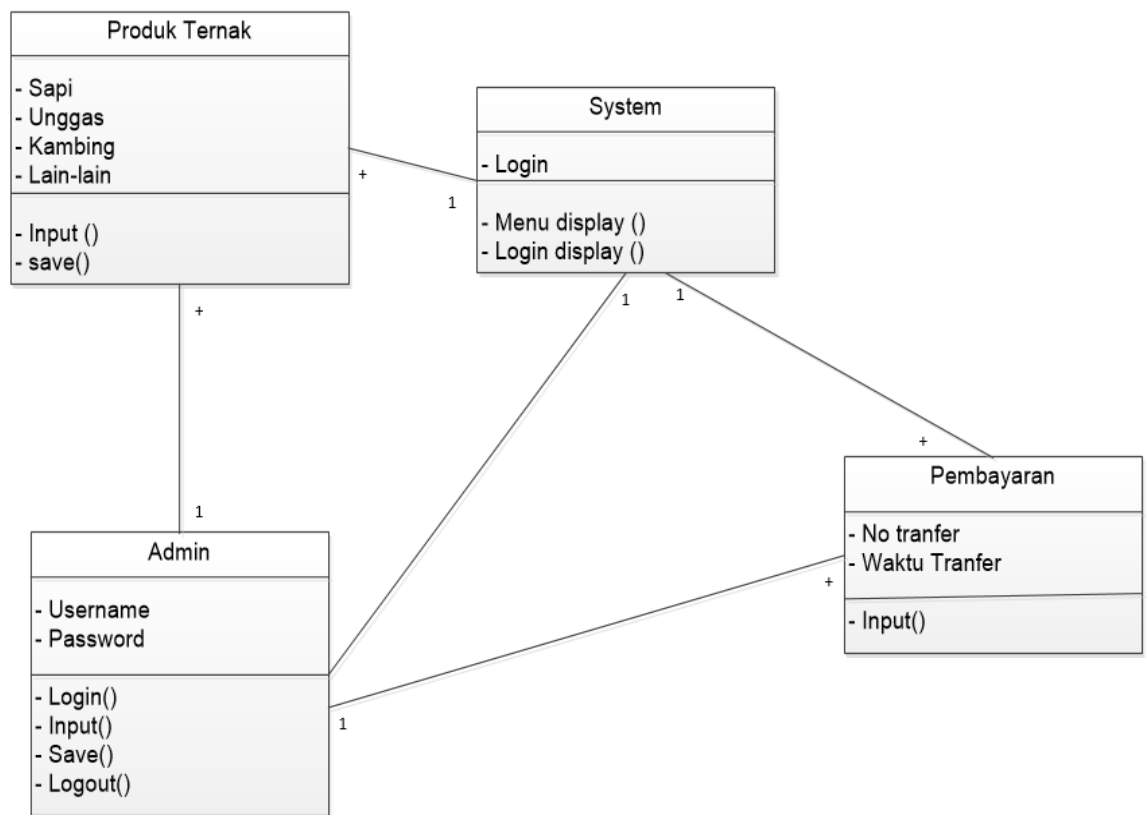

Gambar 9. Class Diagram

\section{KESIMPULAN}

Bedasarkan hasil diskusi, penelitian, dan evaluasi yang dilakukan tentang rancangan website jual beli hewan ternak dan bertujuan untuk mempermudah proses pembelian hewan ternak. Rancangan website sebagai sarana pembelian hewan ternak jika sudah diterapkan bisa membantu dan memberikan kemudahan dalam melakukan proses pembelian hewan ternak. Oleh karena itu, pemilihan kualitas hewan sangat penting untuk pembeli, kondisi hewan harus dalam keadaan sehat dan sesuai syarat yang sudah ditentukan.Tujuan dari penelitian ini adalah untuk merancang aplikasi yang dapat membantu dalam melakukan proses transaksi pembelian hewan ternak dengan mudah. Tujuan peternakan adalah mencari keuntungan dengan penerapan prinsip-prinsip manajemen pada faktor-faktor produksi yang telah dikombinasikan secara optimal.

\section{REFERENSI}

[1] Mulyani, Sri. 2016. Analisis dan Perancangan Sistem Informasi. Jakarta: Abdi Sistematika

[2] Suryana, Aditya, Agustina, Nova, Nur Fauziah, Syifa. (2021) Rancang Bangun Sistem Pengolahan Data Buku Sertifikat Tana Berbasis Web

[3] Firmansyah Yoki, Pitriani (2017) Penerepan Metode SDLC Waterfall dalam Pembuatan Aplikasi Pelyanan Anggota Pada CU Data Usaha Bersama Pontianak

[4] Ahmat Josi (2017) Penetapan Metode Prototiping dalam Pembangunan Website Desa (Stufi Kasus Desa Sugihan Kecamatan Rambang)

[5] Rasyaf, M. 2012. Panduan Beternak Ayam Petelur. Penebar Swadaya. Jakarta.

[6] Pasal 1 Huruf d UU Nomor 6 Tahun 1967 Tentang Ketentuan-Ketentuan Pokok Peternakan Dan Kesehatan Hewan

[7] Pasal 1 Angka 5 UU Nomor 18 Tahun 2009 Tentang Peternakan Dan Kesehatan Hewan 